\title{
Simple and Efficient Method for the Synthesis of Galactofuranosides
}

\author{
Gladys C. Completo ${ }^{*}$, Reymart V. Sangalang ${ }^{2}$, Beatrice M. I. Pique ${ }^{3}$, and Ruel C. \\ Nacario $^{1,3}$
}

${ }^{1}$ Institute of Chemistry, University of The Philippines Los Baños, College, Laguna

${ }^{2}$ Department of Chemistry, De La Salle University, Taft, Manila

${ }^{3}$ Department of Physical Sciences and Mathematics, University of the Philippines Manila, Manila<smiles>CCCC(CC)C(O)C(O)C(O)C(O)CO</smiles>

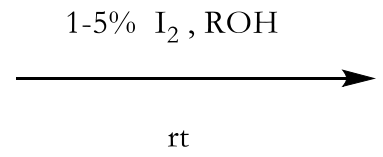

An efficient and improved one-pot method for the synthesis of galactofuranosides via iodine-promoted cyclization of galactose diethyl dithioacetal in the presence of alcohol, acting both as solvent and nucleophile, is described. The reaction is carried out at room temperature. Alcohols, such as methanol, cyclohexanol and tert-butanol, were used as nucleophiles for the reaction using $2 \%, 3 \%$ and $5 \%$ iodine promoter, respectively. A key finding in this study was that the iodine-promoted cyclization of galactose diethyl dithioacetal with alcohol led to selective formation of $\beta$-galactofuranoside allowing the efficient preparation of derivatives of this monosaccharide.

Keywords: carbobydrate; galactofuranose; iodine; gyclization; $\beta$-galactofuranosides

\section{INTRODUCTION}

Monosaccharides found in mammalian cells are in the six-membered pyranose conformation. In lower organisms, such as bacteria, parasites, and fungi, several monosaccharides are observed to be in their furanose form, wherein the linear six carbon sugar is cyclized into a five membered ring. The most common furanoses are the arabinofuranose, galactofuranose, and fructo- furanose (Lowary, 2003). Hexopyranosides are thermodynamically more stable than their furanoside counterparts due to steric, and electronic factors (Plavec et al., 1996). Among the common furanosides, D-galactofuranose (D-Galf) is the only one that occurs naturally. Both the alpha $(\alpha)$ and beta $(\beta)$ anomers of galactofuranose are produced by various lower organisms, with the beta anomer being more prevalent (Lowary, 2003). Several pathogenic 
organisms are thought to produce this thermodynamically less stable and more sterically-hindered conformation of sugar as an important element for their survival. These include Mycobacterium, Trypanosoma, Leishmania and Aspergillus which are responsible for certain species-associated diseases that are difficult to treat (Tefsen et al., 2012).

Galf is one of the components of complex cell wall of pathogenic fungi such as Aspergillus fumigatus that helps prevent lysis (Latge, 2007; Tefsen et al., 2012). Parasitic protozoa such as Trypanosoma and Leishmania, which cause sleeping sickness and Chagas disease, and leishmaniasis respectively, have galactofuranose residues in glycoproteins and glycolipids that account for their virulence (Tefsen et al., 2012). Other applications of galactofuranoses include further study on the prevention of biofilm formation to counteract fungal infections. This is similar to yeast and bacteria biofilms which is mainly composed of galactofuranose containing galactomannans and alpha-glucans (Peltier, 2008; Loussert et al., 2010). Thiodisaccharide Galf-S- $(1 \rightarrow 0)$-Galf-OMe was synthesized and showed a moderate competitive inhibition with the $\beta$-galactofuranoside of Penicillum fellatanum (Repetto, Marino, and Varela, 2013). Another study showed that a 9-heptadecyl galactofuranose thioglycoside and its sulfone displayed a significant inhibitory potency of less than 5 $\mu \mathrm{g} / \mathrm{mL}$ against $M$. smegmatis (Davis et al., 2007).

Thus, Galf-containing cellular components are viewed as putative targets in drug discovery and development of methods to synthesize Galf derivatives is continuously being sought. Methods such as kinetically-controlled Fischer glycosylation (Lubineau and Fischer, 1991; Arasappan and Fraser-Reid, 1995; Velty et al.,1997), high temperature acylation (D'Accorso et al., 1983), cyclization of dithioacetals (Green and Pacsu, 1938), or open-chain S,O-acetals (McAuliffe and Hindsgaul, 1997), ring opening of 1,4-anhydrogalactopyranose derivatives (Kovensky and Sinay, 2000), and formation of 1,2:5:6-di-O-isopropylidene derivatives (Morgenlie, 1973; Wang et al., 2003; Rauter et al., 1995) have been reported.

When hexoses are treated with alcohols under Fischer glycosylation conditions (acid in an alcoholic solvent), furanosides are formed initially, which are then converted to their pyranoside forms (Capon, 1969). Furanosides are considered the kinetic products of this reaction and are often formed in excellent yields as a mixture of anomers, if proper conditions are chosen. D-Galactose was converted to a mixture of anomeric methyl furanosides via a ferric chloride-catalyzed Fischer glycosylation (Lubineau and Fischer, 1991). Fraser-Reid and coworkers also reported a Fischer glycosidation of D-galactose under kinetic conditions using $n$ pentenyl alcohol and camphorsulfonic acid (CSA) at $90-100{ }^{\circ} \mathrm{C}$ for six hours to afford $n$ pentenyl galactofuranoside (5) as a mixture of anomers (Figure 1, Arasappan and Fraser-Reid, 1995). The reaction also gave the corresponding anomeric mixture of pyranosides (6), albeit in poor yield.

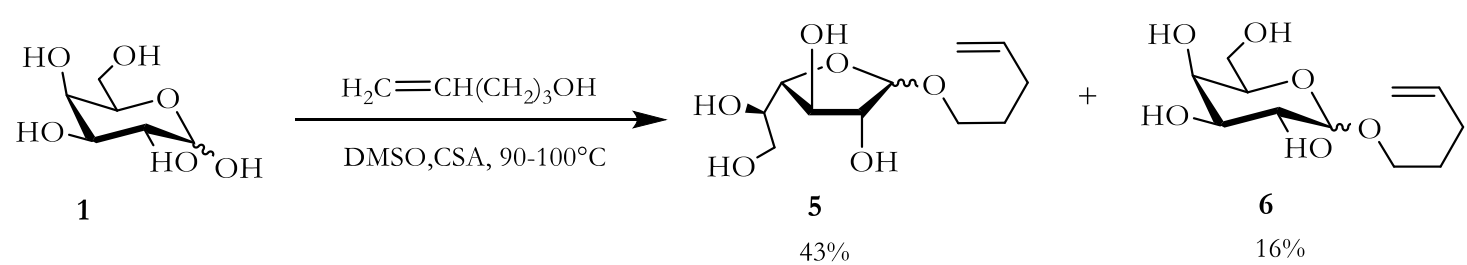

Figure 1. Fischer glycosidation of D-galactose (Arasappan and Fraser-Reid, 1995).

A modified method for glycosylation of 4penten-1-ol with D-galactose was done in tetrahydrofuran using ferric chloride as the promoter and calcium chloride as an additive. The reaction afforded, after 54 hours at room temperature and in situ acetylation, a mixture of furanosides and the corresponding pyranosides with a net preference for $\beta$-furanoside and $\alpha$ pyranoside derivatives (Velty et al., 1997). The favorable formation of the furanoside products over the thermodynamically more stable pyranosides was attributed to the complexation of the furanoside forms by $\mathrm{Ca}^{+2}$ ion (Angyal, 1980). 
The first synthesis of perbenzoylated $\beta$-Dgalactofuranoside (7) and $\alpha$-Dgalactofuranoside (8) was discovered serendipitously in an attempt to prepare 1,2,3,4,5-penta-O-benzoyl- $\beta$-D-galactopyranose

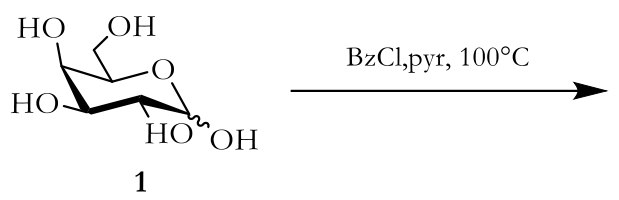

(D'Accorso et al., 1983). Treatment of Dgalactose with benzoyl chloride and pyridine at $100{ }^{\circ} \mathrm{C}$ resulted in the formation of 7 and 8 instead of the target galactopyranoside product (Figure 2).

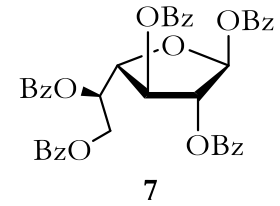

$43 \%$

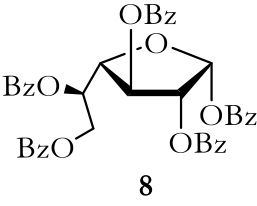

$34 \%$

Figure 2. High temperature benzoylation of D-galactose (D'Accorso et al., 1983).

An unconventional approach to the synthesis of galactofuranosides from galactopyranose involves the reaction of protected 1,4anhydrogalactopyranose derivatives with alcohols in the presence of camphorsulfonic acid for 3-4 days via regioselective ring opening of the bicyclic system to yield the desired galactofuranosides (Kovensky and Sinay, 2000). Another method used acyclic glycosyl dithioacetals as precursors in the synthesis of glycosyl furanosides (Fischer, 1894; Green,
1966; Pacsu and Green, 1936). One example involved the preparation of 1-chloro-1(ethylthio) derivatives (10) of D-glucose and Dgalactose from the corresponding dithioacetal pentaacetates (Figure 3, Wolfrom et al., 1944). The S,O acetals (11) formed were found to undergo regio- and stereoselective cyclization following deacetylation and treatment with a mixture of $\mathrm{HgO}$ and $\mathrm{HgCl}_{2}$ in either methanol or ethanol to give the corresponding $\beta$-Dfuranosides (12).

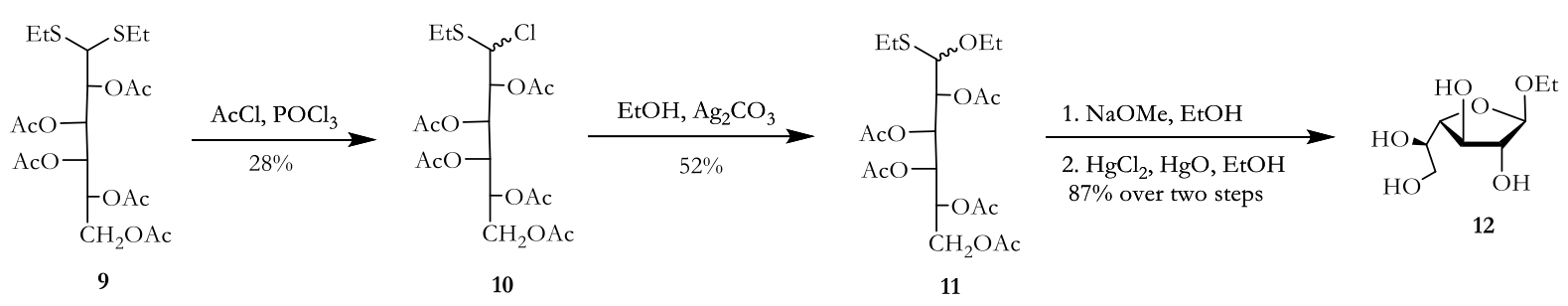

Figure 3. Cyclization of $S, O$ acetals to give ethyl $\beta$-D-galactofuranoside (Wolfrom et al., 1944).

An elegant extension of this method was demonstrated by McAuliffe and Hindsgaul (1997) by treatment of a peracetylated diethyl dithioacetal of $\mathrm{D}$-galactose with acetyl chloride and boron trifluoride diethyl etherate to give the acyclic 1-chloro-(ethylthio) derivative $\mathbf{1 0}$. Glycosidation of acceptor 13 with donor 10 in the presence of $\mathrm{AgOTf}$ and $\mathrm{Ag}_{2} \mathrm{CO}_{3}$, provided $S$,O-acetal 14. Deacetylation of $\mathbf{1 4}$ under Zémplen conditions (Zemplén et al., 1953) followed by addition of $\mathrm{HgO}$ and $\mathrm{HgCl}_{2}$ to the methanolic solution and subsequent acetylation gave $\beta$-galactofuranoside 16 (Figure 4, McAuliffe and Hindsgaul, 1997).

Relevant to these methods is a report involving the 1,3-dibromo-5,5-dimethylhydantoin (DBDH)-mediated activation of glycosyl dithioacetals leading to the formation of glycofuranosides (Madhusudan and Misra, 2005). However, a major disadvantage of these methods is the use of toxic heavy metal salts and expensive reagents. A related methodology that circumvents this limitation is the treatment of glucosyl, mannosyl and arabinosyl dithioacetals with a dilute solution of iodine $\left(\mathrm{I}_{2}\right)$ in methanol to give the corresponding glycosyl furanosides (Szarek et al., 1986).

As shown in Figure 5, stirring dithioacetal $\mathbf{1 7}$ in $1 \% \mathrm{I}_{2}$ in methanol for 32 hours afforded glucofuranoside $\mathbf{1 8}$ in $74 \%$ yield. 
This reaction was only applied to arabinose, glucose and mannose-derived dithioacetals, but not to those derived from galactose. We previously reported adapting this method for the iodine-induced dithioacetal cyclization in octanol towards the synthesis of octyl galactofuranosides (Completo and Lowary,
2008). This was the first reported synthesis of $\beta-$ octyl galactofuranoside using galactose-derived dithioacetal. We now report here an extension of the utility of our method by using other simple and sterically-hindered alcohols, acting as both solvent and nucleophile, in the synthesis of corresponding galactofuranosides (Figure 6).

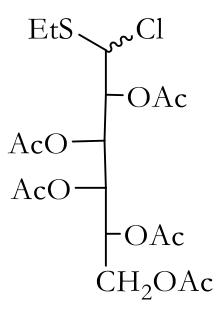

10

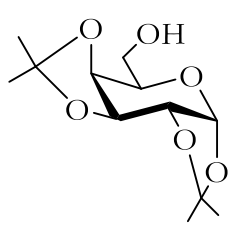

13

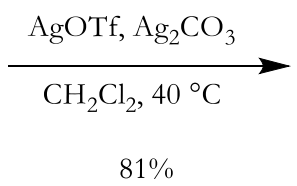

$81 \%$

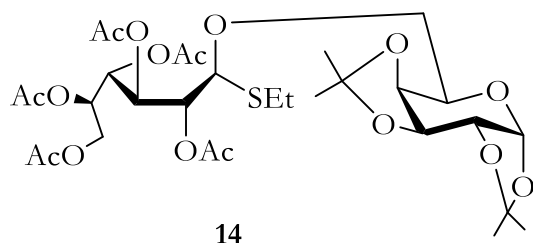

14
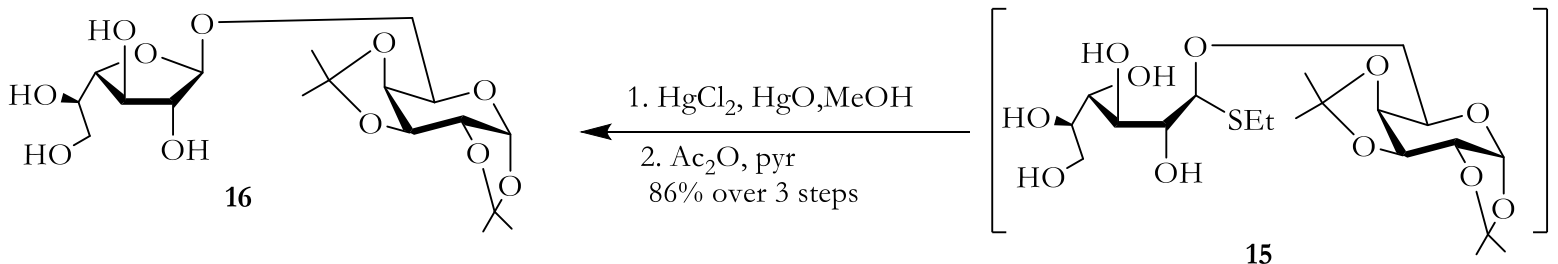

15

Figure 4. Synthesis of galactofuranosides via cyclization of open-chain S,O-acetals (McAuliffe and Hindsgaul, 1997).<smiles>CCC(CC)C(O)C(O)C(O)C(O)CO</smiles><smiles>CO[C@H]1O[C@@H](CO)[C@H](O)[C@H]1O</smiles>

18

Figure 5. Reaction of D-glucose diethyl dithioacetal with $I_{2}$ and methanol (Szarek et al., 1986).<smiles>CCC(CC)C(O)C(O)C(O)C(O)CO</smiles>

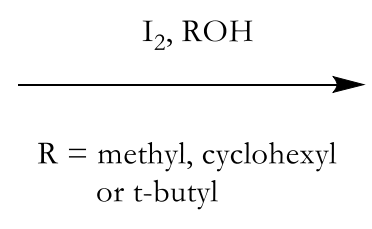

2<smiles>CO[C@H]1O[C@@H](O)[C@@H](CO)[C@H](O)[C@H]1O</smiles>

3<smiles>OCC1C(O)C2OC(O)C(OC3CCCCC3)C1O2</smiles>

4

Figure 6. Use of cyclization of diethyl dithioacetal 2 to prepare alkyl galactofuranosides. 


\section{EXPERIMENTAL METHODS}

General Methods. Reactions were carried out in oven-dried glassware. All reagents were purchased from commercial sources and were used without further purification unless noted. Unless stated otherwise, all reactions were carried out at room temperature under a positive pressure of nitrogen and were monitored by TLC on Silica Gel $60 \mathrm{~F}_{254}(0.25$ $\mathrm{mm}$, E. Merck). TLC spots were detected under UV light or by charring with acidified $p$ anisaldehyde solution in ethanol. All organic solutions were dried with anhydrous $\mathrm{MgSO}_{4}$. Unless otherwise indicated, all column chromatography was performed on Silica Gel (40-60 $\mu \mathrm{M})$. The ratio between silica gel and crude product ranged from 100 to $50: 1$ (w/w). Optical rotations were measured at $22 \pm 2{ }^{\circ} \mathrm{C}$ using Perkin Elmer 241 Polarimeter at the Department of Chemistry, University of Alberta, Edmonton, Canada. ${ }^{1} \mathrm{H}$ NMR spectra were recorded using $500 \mathrm{MHz}$ Agilent or $400 \mathrm{MHz}$ JEOL Lambda NMR spectrometers and chemical shifts were referenced to either trimethylsilane (TMS) $(0.0$ ppm, $\left.\mathrm{CDCl}_{3}\right), \mathrm{CD}_{3} \mathrm{OD}\left(3.30 \mathrm{ppm}, \mathrm{CD}_{3} \mathrm{OD}\right.$ ) or $\mathrm{HOD}\left(4.78 \mathrm{ppm}, \mathrm{D}_{2} \mathrm{O}\right) .{ }^{1} \mathrm{H}$ data were reported as though they were first order. ${ }^{13} \mathrm{C}$ NMR spectra were recorded at $125 \mathrm{MHz}$ or $100 \mathrm{MHz}$ using Agilent or JEOL Lambda NMR spectrometers, respectively. ${ }^{13} \mathrm{C}$ NMR chemical shifts were referenced to internal $\mathrm{CDCl}_{3}\left(77.23 \mathrm{ppm}, \mathrm{CDCl}_{3}\right.$ ), or $\mathrm{CD}_{3} \mathrm{OD}$ (48.9 ppm, $\mathrm{CD}_{3} \mathrm{OD}$ ) or external acetone (31.07, $\left.\mathrm{D}_{2} \mathrm{O}\right)$. Assignments of resonances in NMR spectra were made using ${ }^{1} \mathrm{H}-{ }^{1} \mathrm{H}$ COSY and HMQC experiments. Organic solutions were concentrated under vacuum at $<40{ }^{\circ} \mathrm{C}$. All electrospray ionization (ESI-MS) mass spectral data were obtained using Bruker micrOTOF-Q II mass spectrometer. Mass spectra were recorded on samples suspended in mixtures of THF with $\mathrm{MeOH}$ and added $\mathrm{NaCl}$.

Synthesis of Compounds. D-galactose diethyl dithioacetal (2). D-galactose (50.00 g, $0.278 \mathrm{~mol}$ ) was dissolved at room temperature (rt) in concentrated $\mathrm{HCl}(75 \mathrm{~mL})$. Ethanethiol (50
$\mathrm{mL}$ ) was then added, and the reaction mixture was shaken vigorously, releasing the pressure occasionally. After 3-5 minutes, a definite temperature increase was noted; a little amount of ice and ice water was then added. More ice water was added and the crystalline product formed was filtered and washed with small amount of ice water. Recrystallization from absolute ethanol afforded a pure white crystalline 2 (37.00 g, 47\% yield). ${ }^{1} \mathrm{H}$ NMR $\left(500 \mathrm{MHz}, \mathrm{CDCl}_{3}, \delta_{\mathrm{H}}\right) 4.13(\mathrm{dd}, 1 \mathrm{H}, J=9.0$, $1.5 \mathrm{~Hz}, \mathrm{H}-5), 4.07$ (d, $1 \mathrm{H}, J=10.0 \mathrm{~Hz}, \mathrm{H}-1$ ), $3.91(\mathrm{dd}, 1 \mathrm{H}, J=9.0,1.5 \mathrm{~Hz}, \mathrm{H}-3), 3.88$ (dd, $1 \mathrm{H}, 1 \mathrm{H}, J=10.0,1.5 \mathrm{~Hz}, \mathrm{H}-2), 3.64(\mathrm{~d}, 1 \mathrm{H}$, $J=9.0 \mathrm{~Hz}, \mathrm{H}-4), 3.62(\mathrm{~d}, 2 \mathrm{H}, J=7.0 \mathrm{~Hz}, \mathrm{H}-$ $\left.6_{a}, H-6_{b}\right), 2.77-2.65\left(\mathrm{~m}, 4 \mathrm{H}, 2\right.$ x $\left.\mathrm{SCH}_{2}\right), 1.27-$ $1.23\left(\mathrm{~m}, 6 \mathrm{H}, 2 \times \mathrm{CH}_{3}\right) ;{ }^{13} \mathrm{C}$ NMR $(125 \mathrm{MHz}$, $\left.\mathrm{CDCl}_{3}, \delta_{\mathrm{C}}\right) 72.8,71.9,71.8,71.1(\mathrm{C}-2, \mathrm{C}-3, \mathrm{C}-$ 4, C-5), 65.1 (C-6), 56.4 (C-1), 25.4, 25.4 (2 x ethyl $\left.\mathrm{CH}_{2}\right), 14.9,14.8\left(2 \mathrm{x}\right.$ ethyl $\left.\mathrm{CH}_{3}\right)$. ESIMS $m / z$ calcd. for $(\mathrm{M}+\mathrm{Na}) \mathrm{C}_{10} \mathrm{H}_{22} \mathrm{O}_{5} \mathrm{~S}_{2} \mathrm{Na}$ : 309.0806. Found: 309.0897.

Metbyl $\alpha / \beta$-D-galactofuranoside (3). Dithioacetal 2 $(5.90 \mathrm{~g}, 0.14 \mathrm{~mol})$ was dissolved in $2 \% \mathrm{I}_{2}$ in $\mathrm{MeOH}(\mathrm{w} / \mathrm{v}, 295 \mathrm{~mL}$ ) at $\mathrm{rt}$ and stirred for $7 \mathrm{~h}$. Excess $\mathrm{I}_{2}$ was quenched by incremental addition of solid sodium thiosulfate $\left(\mathrm{Na}_{2} \mathrm{~S}_{2} \mathrm{O}_{3}\right)$ until the $\mathrm{I}_{2}$ color diminished. This was followed by the addition of solid sodium bicarbonate $\left(\mathrm{NaHCO}_{3}\right)$ to neutralize the reaction mixture. Evaporation of the solvent gave $35(\beta / \alpha=9: 1)$ as a yellow solid (21.20 $\mathrm{g}$, $78 \%$ ). $R_{f} 0.34$ (6:1 $\left.\mathrm{CH}_{2} \mathrm{Cl}_{2}-\mathrm{MeOH}\right) ; \beta$-isomer (isolated pure after column chromatography): $[\alpha]_{\mathrm{D}}-20.6$ (c 1.1, $\left.\mathrm{CH}_{3} \mathrm{OH}\right) ;{ }^{1} \mathrm{H}$ NMR $(400$ $\left.\mathrm{MHz}, \mathrm{D}_{2} \mathrm{O}, \delta_{\mathrm{H}}\right) 4.83$ (s, $\left.1 \mathrm{H}, \mathrm{H}-1\right), 3.98-3.92$ (m, $2 \mathrm{H}, \mathrm{H}-4, \mathrm{H}-5), 3.88$ (dd, $1 \mathrm{H}, J=4.3,4.3$ $\mathrm{Hz}, \mathrm{H}-3$ ), 3.77-3.73 (m, $1 \mathrm{H}, \mathrm{H}-2$ ), 3.66-3.64 (m, $\left.2 \mathrm{H}, \mathrm{H}-\mathrm{G}_{\mathrm{a}}, \mathrm{H}-\mathrm{G}_{\mathrm{b}}\right), \quad\left(3.45\right.$ (s, $\left.3 \mathrm{H}, \mathrm{OCH}_{3}\right)$; ${ }^{13} \mathrm{C}$ NMR $\left(100 \mathrm{MHz}, \mathrm{D}_{2} \mathrm{O}, \delta_{\mathrm{C}}\right) 108.6$ (C-1), 83.3 (C-2), 81.6 (C-4), 71.3 (C-3), 71.1 (C-5), $63.2(\mathrm{C}-6), 55.4\left(\mathrm{OCH}_{3}\right)$. ESI-MS $\mathrm{m} / \mathrm{z}$ calcd. for $(\mathrm{M}+\mathrm{Na}) \mathrm{C}_{7} \mathrm{H}_{14} \mathrm{O}_{6} \mathrm{Na}$ : 217.0688. Found: 217.0758.

Methyl 2,3,5,6-tetra-O-benzoyl- $\beta$-D-galactofuranoside (20). Dithioacetal 3 (5.90 g, $14.0 \mathrm{mmol})$ was dissolved in $295 \mathrm{~mL}$ of $2 \%(\mathrm{w} / \mathrm{v})$ iodine in methanol in a round bottom flask at room 
temperature for 7 hours. Increments of sodium thiosulfate were added in the solution to remove excess $\mathrm{I}_{2}$. A small amount of sodium bicarbonate was added to neutralize the solution. Evaporation of the solvent gave a yellow solid methyl $\alpha / \beta$-D-galactofuranoside (3). $\mathrm{R}_{\mathrm{f}} 0.31\left(4: 1 \mathrm{CH}_{2} \mathrm{Cl}_{2}: \mathrm{MeOH}\right)$. ESI-MS m/z calcd. for $(\mathrm{M}+\mathrm{Na}) \mathrm{C}_{7} \mathrm{H}_{14} \mathrm{O}_{6} \mathrm{Na}$ : 217.0682. Found: 217.1001.

This solid product was carried over to the next step of benzoylation by dissolving $\mathbf{3}$ with $70.0 \mathrm{~mL}$ of pyridine at $0^{\circ} \mathrm{C}$. Benzoyl chloride $(12.0 \mathrm{~mL}, 0.103 \mathrm{mmol}$ ) was added dropwise while maintaining the temperature. The mixture was allowed to stir overnight after the addition while warming to room temperature. The mixture was quenched by adding icewater to remove the excess benzoyl chloride, and diluted with approximately $150 \mathrm{~mL}$ of dichloromethane. The organic layer was washed successively with water, two portions of $1 \mathrm{M} \mathrm{HCl}$, and saturated aqueous solution of sodium bicarbonate. The organic solution was dried with the addition of sodium sulfate and the solvent was evaporated. The crude product was purified using column chromatography (3:1 Hexane:EtOAc) to yield 20 (8.98 g, $14.71 \mathrm{mmol}, 71 \%$ over two steps). $\mathrm{R}_{\mathrm{f}} 0.25$ (3:1 Hexane:EtOAc); $[\alpha]_{\mathrm{D}}-20.6$ (c 1.1, $\left.\mathrm{CHCl}_{3}\right) ;{ }^{1} \mathrm{H}$ NMR $\left(500 \mathrm{MHz}, \mathrm{CDCl}_{3}, \delta_{\mathrm{H}}\right) 8.20-$ 7.95 (m, $8 \mathrm{H}, \mathrm{Ar}), 7.58-7.35(\mathrm{~m}, 12 \mathrm{H}, \mathrm{Ar})$, $6.15(\mathrm{~m}, 1 \mathrm{H}, \mathrm{H}-5), 5.71(\mathrm{~d}, 1 \mathrm{H}, J=5.3 \mathrm{~Hz}$, $\mathrm{H}-3$ ), 5.55 (s, $1 \mathrm{H}, \mathrm{H}-2), 5.27$ (s, $1 \mathrm{H}, \mathrm{H}-1$ ), 4.85 (m, $\left.2 \mathrm{H}, \mathrm{H}-\mathrm{G}_{\mathrm{a}}, \mathrm{H}-\mathrm{G}_{\mathrm{b}}\right), 4.74$ (dd, $1 \mathrm{H}, J=$ 5.0, $3.9 \mathrm{~Hz}, \mathrm{H}-4), 3.52$ (s, $\left.3 \mathrm{H}, \mathrm{OCH}_{3}\right) ;{ }^{13} \mathrm{C}$ NMR $\left(125 \mathrm{MHz}, \mathrm{CDCl}_{3}, \delta_{\mathrm{c}}\right): 166-165(\mathrm{C}=\mathrm{O})$, 134-133 (Ar), 130-128 (Ar), 106.9 (C-1), 82.2 (C-2), 81.3 (C-4), 77.7 (C-3), 70.4 (C-5), 63.6 (C-6), $55.1\left(\mathrm{OCH}_{3}\right)$. ESI-MS m/z calcd. for $(\mathrm{M}+\mathrm{Na}) \quad \mathrm{C}_{35} \mathrm{H}_{30} \mathrm{O}_{10} \mathrm{Na}$ : 633.1731. Found: 633.2075 .

\section{Cyclohexyl a/ $\beta$-D-galactofuranoside (4).}

Dithioacetal 2 (302.6 mg, $1.06 \mathrm{mmol})$ was dissolved in 3\% $\mathrm{I}_{2}$ in cyclohexanol (w/v, 10 $\mathrm{mL}$ ) at $\mathrm{rt}$ and stirred for $24 \mathrm{~h}$. Excess $\mathrm{I}_{2}$ was quenched by incremental addition of solid $\mathrm{Na}_{2} \mathrm{~S}_{2} \mathrm{O}_{3}$ until the $\mathrm{I}_{2}$ color diminished. This was followed by the addition of $\mathrm{NaHCO}_{3}$ to neutralize the reaction mixture. Evaporation of the solvent gave $4(\beta / \alpha=5.4: 1)$ as a yellow solid (152.60 mg, 55\%). $R_{f} 0.45(\boldsymbol{\alpha}), 0.41(\boldsymbol{\beta})$ $(7: 1 \quad \mathrm{DCM}-\mathrm{MeOH}) ; \quad) ;[\alpha]_{\mathrm{D}}-10.5$ (c 1.2 , $\mathrm{MeOH}) ;{ }^{1} \mathbf{H}$ NMR $\left(400 \mathrm{MHz}, \mathrm{D}_{2} \mathrm{O}\right): \delta_{\mathrm{H}} 5.17$ $(1 \mathrm{H}, \mathrm{d}), 5.12(1 \mathrm{H}, \mathrm{d}), 4.06(1 \mathrm{H}, \mathrm{dd}), 3.99$ (1 $\mathrm{H}, \mathrm{dd}), 3.95(1 \mathrm{H}, \mathrm{dd}), 3.82(1 \mathrm{H}, \mathrm{dt}), 3.65-$ $3.60(3 \mathrm{H}, \mathrm{m}), 1.72(\mathrm{~s}, 4 \mathrm{H}), 1.27(6 \mathrm{H}, \mathrm{m}) ;{ }^{13} \mathrm{C}$ NMR $\left(100 \mathrm{MHz}, \mathrm{D}_{2} \mathrm{O}\right): \delta_{\mathrm{C}} 106.24,100.16$, 82.86, 82.03, 78.52, 76.99, 71.65, 63.81, 34.19, 26.10, 24.98. ESI-MS: $\mathrm{m} / \mathrm{z}(\mathrm{M}+\mathrm{Na})^{+}: 285.1$

Tert-butyl a/ $\beta$-D-galactofuranoside (5). $\left(\mathrm{C}_{10} \mathrm{H}_{20} \mathrm{O}_{6}\right)$. Dithioacetal $2(300.0 \mathrm{mg}, 1.05 \mathrm{mmol})$ was dissolved in $5 \% \mathrm{I}_{2}$ in $t$-butyl alcohol $(\mathrm{w} / \mathrm{v}$, $10.17 \mathrm{~mL}$ ) at $\mathrm{rt}$ and stirred for $24 \mathrm{~h}$. Excess $\mathrm{I}_{2}$ was quenched by incremental addition of solid $\mathrm{Na}_{2} \mathrm{~S}_{2} \mathrm{O}_{3}$ until the $\mathrm{I}_{2}$ color diminished. This was followed by the addition of $\mathrm{NaHCO}_{3}$ to neutralize the reaction mixture. Evaporation of the solvent gave $5(\beta / \alpha=1: 1)$ as a yellow solid (135.10 mg, 54.42\%). $R_{f} 0.32(\boldsymbol{\alpha}), 0.38$ ( $\beta)(7: 1 \mathrm{DCM}-\mathrm{MeOH}) ;{ }^{1} \mathbf{H}$ NMR $(400 \mathrm{MHz}$, $\left.\mathrm{CD}_{3} \mathrm{OD}\right): \delta_{\mathrm{H}} 5.50(1 \mathrm{H}, \mathrm{s}), 5.15(1 \mathrm{H}, \mathrm{d}), 4.00$ (1 H, dd), 3.94 ( $1 \mathrm{H}, \mathrm{dd}), 3.88$ (1 H, dd), 3.77 $(1 \mathrm{H}, \mathrm{m}), 3.64(3 \mathrm{H}, \mathrm{m}), 1.26(9 \mathrm{H}, \mathrm{s}) ;{ }^{13} \mathrm{C}$ NMR $\left(100 \mathrm{MHz}, \mathrm{CD}_{3} \mathrm{OD}\right): \delta_{\mathrm{C}} 104.30,97.53$, 84.02, 83.56, 78.22, 76.06, 72.43, 64.67, 29.20. ESI-MS: $\mathrm{m} / \mathrm{z}(\mathrm{M}+\mathrm{Na})^{+}: 259.1$.

\section{RESULTS AND DISCUSSION}

Several methods for the conversion of acyclic sugar dithioacetals to $\beta$-D-furanosides have been reported but the use of toxic heavy metals and expensive reagents preclude its general utility (McAuliffe and Hindsgaul, 1997; Madhusudan and Misra, 2005).

A modified method circumventing this limitation is the iodine-promoted cyclization of glucosyl, mannosyl and arabinosyl-derived dithioacetals in methanol to give the corresponding glycosyl furanosides (Szarek et al, 1986). Likewise, we were the first to report the use of galactose-derived dithioacetal in a similar reaction (Completo and Lowary, 2008). The major advantage of this dithioacetal cyclization reaction in preparing galactofuranosides is its simplicity. Not only does this technique avoid the use of toxic heavy metals, it is also inexpensive, simple 
and, most importantly, provides high yield of galactofuranosides without or minimal formation of galactopyranosides. We applied this method in the synthesis of methyl and octyl galactofuranosides as intermediates for the preparation of molecular probes of a mycobacterial cell wall enzyme galactofuranosyltransferase (Rose et al., 2006; Belánová et al., 2008).

The proposed mechanism for the iodinepromoted cyclization reaction is shown in Figure 7. The initial step involves the nucleophilic attack of one of the sulfur atoms of 2 on the electrophilic iodine to form sulfonium ion 19. Iodine is a soft acid (Pearson, 1987) and it easily complexes with the sulfur atom of one of the thiol groups to form a sulfonium ion. The sulfonium ion, being a good leaving group, can then be easily cleaved to form thiocarbenium 20. Subsequent cyclization of 20 gives thioglycoside 21, which then reacts with another molecule of iodine to generate intermediate 22. Loss of ethyl sulfenium iodide leads to oxacarbenium intermediate $\mathbf{2 3}$, which can be attacked by an alcohol such as methanol, acting as both solvent and nucleophile, to give methyl glycoside $\mathbf{3}$.

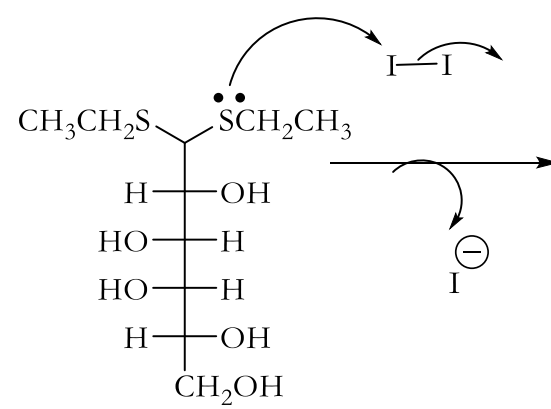

2

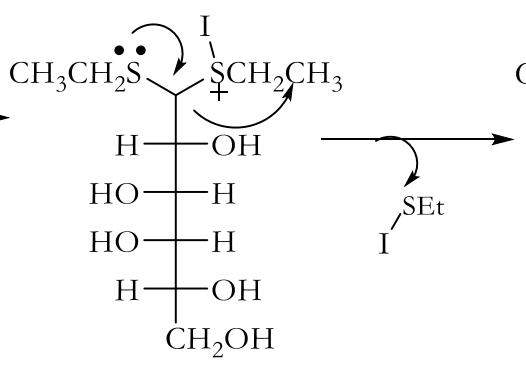

19

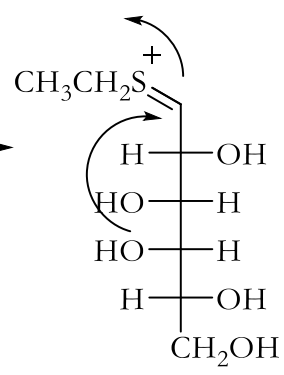

20
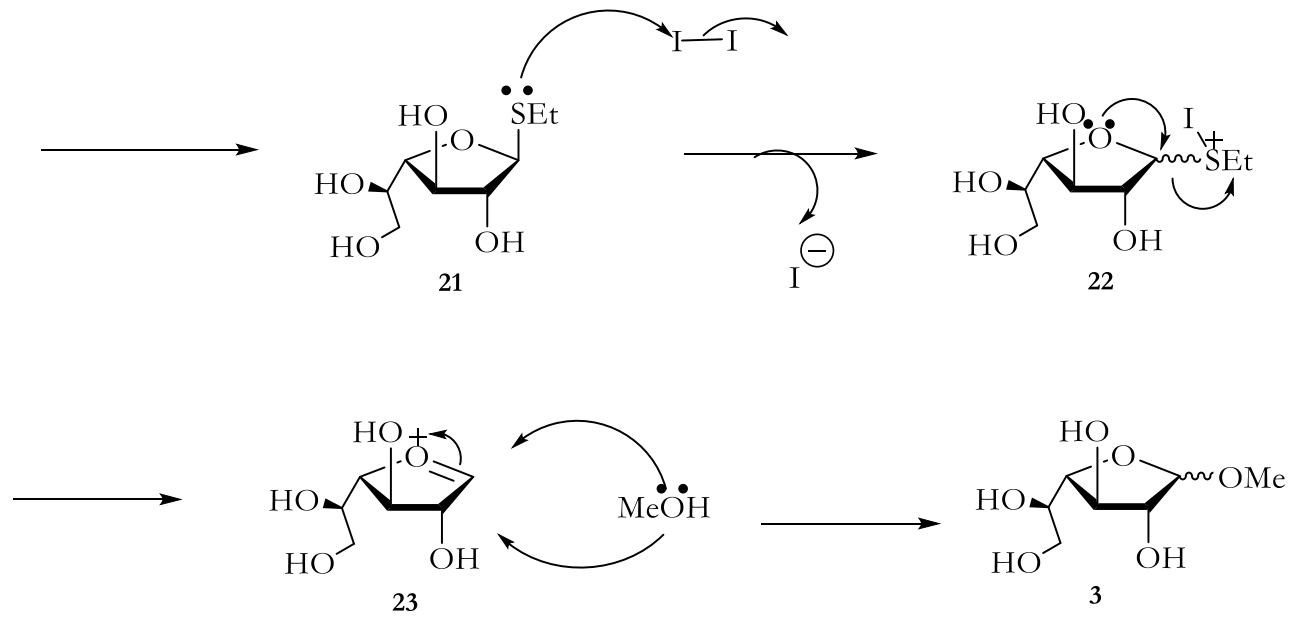

Figure 7. Proposed mechanism of iodine-induced dithioacetal cyclization in methanol.

Synthesis of Methyl galactofuranoside 3 and Perbenzoylated methyl galactofuranoside 24. Further extension of this method was applied in the synthesis of a perbenzoylated methyl galactofuranoside 24 . To implement this approach, D-galactose 1 was treated with ethanethiol and $\mathrm{HCl}$ to give diethyl dithioacetal 2 in $47 \%$ yield using an established method (Wolfrom, 1940). This was followed by the iodine-promoted cyclization of intermediate $\mathbf{2}$ to methyl galactofuranoside 3 (Figure 8). Table 1 shows the different iodine concentrations used to obtain the optimal conditions in the synthesis of methyl galactofuranoside 3 . We observed that the reaction rate was dependent on iodine concentration. Although the use of higher concentrations of iodine $(3-5 \%)$ resulted in shorter reaction times, this, however, resulted in the formation of significant amount of salt 
that hindered purification of the product. It was only during reactions beyond $24 \mathrm{~h}$ that we start to observe (via thin layer chromatography) the increase in the formation of the $\alpha$ anomer product. Thus, it was necessary to use lower iodine concentration $(2 \%)$ without significant effect in the ratio (average $\alpha: \beta$ ratio of 8-9:1) and yield (74-78\%) obtained for the product. Thus, cyclization of intermediate 2 was effected by treatment with $2 \% \mathrm{I}_{2}$ (by weight, $0.08 \mathrm{M}$ ) in methanol to give intermediate 3 (Figure 8). The reaction was quenched by adding solid $\mathrm{Na}_{2} \mathrm{~S}_{2} \mathrm{O}_{3}$ until the solution turned colorless. The solution was then neutralized with solid $\mathrm{NaHCO}_{3}$ and the solvent was evaporated under reduced pressure. However, the formation of solid salts during work-up and the polar nature of the product (intermediate 3 ) made purification difficult. This prompted us to perform the benzoylation reaction without purification of crude intermediate 3 . Therefore, pyridine was added to the crude methyl galactofuranoside 3 , followed by dropwise addition of benzoyl chloride. The resulting perbenzoylated product, 24, was obtained in $71 \%$ yield over two steps after purification by column chromatography.

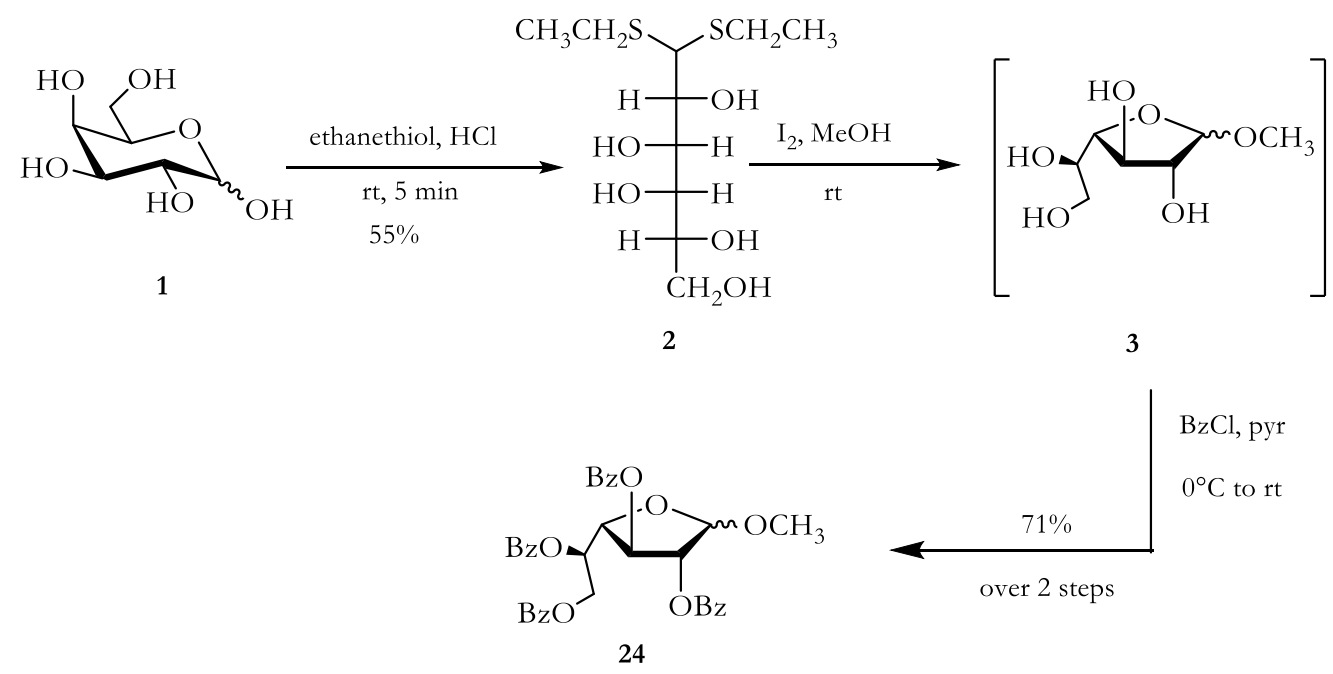

Figure 8. Preparation of Methyl galactofuranoside 24 via Cyclization of Dithioacetal.

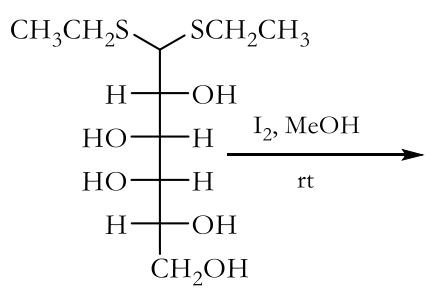<smiles>CO[C@@H]1O[C@H](C(O)CO)[C@@H](O)[C@H]1O</smiles>

3

Table 1. Synthesis of 3 as a Function of Iodine Concentration.

\begin{tabular}{cccc}
\hline $\begin{array}{c}\text { Concentration } \\
(\mathrm{w} / \mathrm{v})\end{array}$ & $\begin{array}{c}\text { Time } \\
(\mathrm{h})\end{array}$ & Yield & $\begin{array}{c}\text { Product } \\
\text { Ratio } \\
(\beta: \alpha)\end{array}$ \\
\hline $1 \%$ & 24 & $74 \%$ & $(8.2: 1)$ \\
\hline $2 \%$ & 8 & $78 \%$ & $(9: 1)$ \\
\hline $3 \%$ & 3 & $77 \%$ & $(9.2: 1)$ \\
\hline $4 \%$ & 2 & $78 \%$ & $(9.2: 1)$ \\
\hline $5 \%$ & $<1$ & $76 \%$ & $(9.3: 1)$ \\
\hline
\end{tabular}

Using ${ }^{1} \mathrm{H}$ and ${ }^{13} \mathrm{C}$ NMR spectroscopy, we were able to discriminate between the formation of the $\alpha$ and $\beta$-configuration of the product. The singlet signal of the anomeric hydrogen $\left(\delta_{\mathrm{H}}=\right.$ $5.80 \mathrm{ppm}$ ) established the trans relationship between $\mathrm{H}-1$ and $\mathrm{H}-2$. A cis relationship between $\mathrm{H}-1$ and $\mathrm{H}-2$ would have shown a larger coupling constant $\left(J_{1,2}=3-5 \mathrm{~Hz}\right)(\mathrm{Cyr}$ and Perlin, 1979). Also, the chemical shift of the anomeric carbon of $\mathbf{2 4}$ was shifted downfield $\left(\delta_{\mathrm{c}}=106.9 \mathrm{ppm}\right)$ compared to the more upfield shift $\left(\delta_{\mathrm{c}} \sim 103 \mathrm{ppm}\right)$ of the anomeric carbon of an $\alpha$-product ( $\mathrm{Cyr}$ and Perlin, 1979). In addition to this, the C-2 and C-4 signals resonated at 82.2 and $81.2 \mathrm{ppm}$, respectively. These signals are significantly more downfield than the carbons in pyranosides and, thus, conclusively establish the furanose ring form of 24 . The observed ${ }^{1} \mathrm{H}$ 
NMR and ${ }^{13} \mathrm{C}$ NMR data were consistent with the previously reported characteristic signal pattern for $\beta$-D-galactofuranosides (Cyr and Perlin, 1979) and with our results (Completo and Lowary, 2008).

\begin{abstract}
Synthesis of Cyclohexyl- $\alpha / \beta$-galactofuranoside 4. Encouraged by these observations, we explored the general applicability of this method using more sterically hindered alcohols such as a secondary alcohol cyclohexanol. We anticipated that the hindered nature of cyclohexanol will require higher iodine concentration, thus, 3\% iodine was used for the reaction. Indeed, it took 24 hours of continuous stirring to guarantee completion of the reaction. The cyclohexyl galactofuranoside 4 was obtained in $55 \%$ yield with 1:5.4 $\alpha: \beta$ product ratio. The ${ }^{1} \mathrm{H}$ NMR spectral data showed the alpha anomeric proton as a doublet at $5.17 \mathrm{ppm}$, while the beta anomeric proton gave a doublet at $5.12 \mathrm{ppm}$. This was confirmed by their ${ }^{3} \mathrm{~J}_{1,2}$ values of 4.6 and $2.8 \mathrm{~Hz}$, respectively, that is consistent with the characteristics of alkyl furanosides (Cyr and Perlin, 1979). The ${ }^{13} \mathrm{C}$ NMR spectra showed the $\alpha$ and $\beta$ anomeric carbons resonating at 100.16 and $106.24 \mathrm{ppm}$, respectively. These data were consistent with the expected chemical shifts for hexofuranosides (Bock and Pedersen, 1983).
\end{abstract}

\section{Synthesis of tert-Butyl- $\alpha / \beta$-galacto-}

furanoside 5. The use of tertiary alcohol, such as tert-butyl alcohol, was also explored. Due to the more hindered nature of tert-butyl alcohol and its weaker nucleophilicity, higher iodine concentration $(5 \% \mathrm{w} / \mathrm{v})$ was used to form the tert-butyl- $\alpha / \beta$-galactofuranoside. The ${ }^{1} \mathrm{H}$ NMR signal for the $\beta$ and $\alpha$-protons were observed at $5.5 \mathrm{ppm}$ and $5.15 \mathrm{ppm}$ having ${ }^{3} \mathrm{~J}_{1,2}$ values of 0 and $2.5 \mathrm{~Hz}$, respectively, in a 1:1 ratio. A cis relationship between $\mathrm{H}-1$ and $\mathrm{H}-2$ of furanosides is expected to give a ${ }^{3} J_{1,2}$ coupling constant of greater than 3, while a trans relationship should have a coupling constant between 0 to 3 (Cyr and Perlin, 1979). The experimental ${ }^{3} J_{1,2}$ values obtained were consistent with the expected literature values indicative of $\alpha$ and $\beta$ Gal $f$ anomeric hydrogens. From the ${ }^{13} \mathrm{C}$ NMR spectrum, the chemical shift of the $\beta$ anomeric carbon was observed at $104.30 \mathrm{ppm}$, consistent with the signal of the expected anomeric carbon position for galactofuranosides (Bock and Pedersen, 1983). The ${ }^{13} \mathrm{C}$ chemical shifts for C-2 and C-4 were observed at 83.56 and $84.02 \mathrm{ppm}$, respectively. These are consistent with characteristic ${ }^{13} \mathrm{C}$ signals for furanose ring carbons resonating more downfield than pyranose ring carbons, thus further establishing that tert-butyl- $\beta$-galactofuranoside was formed.

The use of varying concentration of iodine is dependent on the steric bulkiness of the alkyl component of the alcohol used and which greatly affects the reaction time. The use of more sterically-hindered alcohol required higher iodine concentration as the promoter for the reaction to proceed to completion, else more than $24 \mathrm{~h}$ is needed to complete the reaction. Further method optimization is ongoing in our laboratory to improve the yield of the reaction using more hindered alcohols. To date, this is the first time that an iodinepromoted dithioacetal cyclization was used in preparing more sterically hindered alkyl furanosides. The application of this method in the synthesis of disaccharides is also being pursued in our laboratory.

\section{CONCLUSION}

In summary, we have demonstrated that a simple and efficient iodine-promoted cyclization of galactose-derived dithioacetal towards the synthesis of galactofuranoside derivatives can be effected using, not just primary alcohols, but also more stericallyhindered alcohols acting as both solvent and nucleophile. The results showed that alcohols with varying steric bulk such as methanol, cyclohexanol and tert-butanol acting as nucleophiles using 2\%, 3\% and 5\% iodine as promoter, respectively, led to the selective formation of $\beta$-galactofuranoside derivatives in moderate to good yields. Further method optimization is underway in our laboratory to improve the yield of the reaction. 


\section{REFERENCES}

Angyal SJ. Sugar-cation complexes-structure and applications. Chem Soc Rev. 1980; 9, 415428.

Arasappan A, Fraser-Reid B. n-Pentenyl furanosides: synthesis and glycosidation reactions of some galacto derivatives. Tet Lett.1995; 36(44), 7967-7970.

Belanova, M; Dianiskova, P; Brennan, PJ; Completo, GC; Rose, NL; Lowary, TL; Mikusova, K. Galactosyl transferases in mycobacterial cell wall synthesis. J Bacteriol. 2008, 190, 1141-1145.

Besra GS, Khoo KH, McNeil MR, Dell A, Morris HR, Brennan PJ. A new interpretation of the structure of the mycolylarabinogalactan complex of Mycobacterium tuberculosis as revealed through characterization of oligoglycosylalditol fragments by fast-atom bombardment mass spectrometry and ${ }^{1} \mathrm{H}$ nuclear magnetic resonance spectroscopy. Biochem. 1995; 34(13), 4257-4266.

Bock K, Pedersen C. Carbon-13 nuclear magnetic resonance spectroscopy of monosaccharides. Adv Carb Chem Biochem. 1983; 41, 27-66.

Brennan PJ. Structure, function, and biogenesis of the cell wall of Mycobacterium tuberculosis. Tuber. 2003; 83(1), 91-97.

Brennan PJ, Nikaido $H$. The envelope of mycobacteria. Ann Rev Biochem. 1995; 64(1), $29-63$.

Campaigne E, and Leal JR. $\alpha, \beta$-Unsaturated Sulfides. The Reaction of Thiophenol with Certain Ketones1. J Am Chem Soc. 1954; 76(5), 1272-1275.

Capon B. Mechanism in carbohydrate chemistry. Chem Rev. 1969; 69, 407-498.
Chatterjee D. The mycobacterial cell wall: structure, biosynthesis and sites of drug action. Curr Opin Chem Bio. 1997; 1(4), 579588.

Compain P, Martin OR. Carbohydrate mimetics-based glycosyltransferase inhibitors. Biorg Med Chem. 2001: 9(12), 3077-3092.

Completo, GCJ. Synthesis of Galactofuranosides for the Characterization of Galactofuranosyltransferases Involved in Mycobacterial Arabinogalactan Biosynthesis. Alberta: University of Alberta; 2008. ProQuest.

Completo GCJ, Lowary TL. Synthesis of galactofuranose-containing acceptor substrates for mycobacterial galactofuranosyltransferases. J Org Chem. 2008; 73(12), 4513-4525.

Cren S, Gurcha SS, Blake, AJ, Besra GS, Thomas NR. Synthesis and biological evaluation of new inhibitors of UDP-Galf transferase-a key enzyme in $M$. tuberculosis cell wall biosynthesis. Org Biomol Chem. 2004; 2(17), 2418-2420.

Cyr N, Perlin AS. The conformations of furanosides. $\mathrm{A}{ }^{13} \mathrm{C}$ nuclear magnetic resonance study. Can J Chem. 1979; 57(18), 2504-2511.

D'Accorso, NB, Thiel IME, Schuller M. Proton and $\mathrm{C}-13$ nuclear magnetic resonance spectra of some benzoylated aldohexoses. Carbohydr Res. 1983; 124, 177-184.

Damager I, Engelsen SB, Blennow A, Lindberg Møller B, Motawia, MS. First principles insight into the $\alpha$-glucan structures of starch: their synthesis, conformation, and hydration. Chem Rev. 2010; 110(4), 20492080.

Davis CB, Hartnell RD, Madge PD, Owen DJ, Thomson RJ, Chong AK, et al. Synthesis and biological evaluation of galactofuranosyl alkyl thioglycosides as inhibitors of mycobacteria. Carbohydr Res. 2007; 342(12), 1773-1780. 
Fischer E. Ueber die Verbindungen der Zuckerarten mit den Mercaptanen Ber. 1894, 27, 673-679.

Green JW, Pacsu E. Glycofuranosides and Thioglycofuranosides. I. A Method of Preparation and its Application to Galactose and Glucose. J Am Chem Soc. 1. 1937; 59(7), 1205-1210.

Green JW, Pacsu EJ. New crystalline furanosides of D- galactose and L-arabinose J Am Chem Soc.1938; 87, 5469-5472.

Green JW. The glycofuranosides. Adv Carbohydr Chem Biochem. 1966; 21, 95-142.

Hanessian S. Editor. 1997. Preparative carbohydrate chemistry. CRC Press.

Kovensky J, Sinay P. Synthesis of Galactofuranosides by Regioselective Ring Opening of a 1,4-Anhydrogalactopyranose Derivative: A Possible Chemical Model for an Unprecedented Enzymatic Reaction. Eur J Org Chem. 2000; 3523-2525.

Latge JP. Galactofuranose containing molecules in Aspergillus fumigatus. Med Mycol. 2009; 47, Suppl 1: S104-9.

Lin KC. Understanding product optimization: Kinetic versus thermodynamic control. J Chem Ed.1988; 65(10), 857.

Loussert C, Schmitt C, Prevost MC, Balloy V, Fadel E, Philippe B, et al. In vivo biofilm composition of Aspergillus fumigatus. Cell Microb. 2010;12(3), 405-410.

Lowary TL. Synthesis and conformational analysis of arabinofuranosides, galactofuranosides and fructofuranosides. Curr Opin Chem Bio. 2003; 7(6), 749-756.

Lubineau A, Fischer JC. High-yielding onestep conversion of D-glucose and D-galactose to the corresponding methyl $\alpha-$ and $\beta$ glucofuranosides and galactofuranosides. Synth Commun. 1991; 21, 815-818
Ma Y, Stern RJ, Scherman M S, Vissa VD, Yan W, Jones VC et al. Drug targeting Mycobacterium tuberculosis cell wall synthesis: genetics of dTDP-rhamnose synthetic enzymes and development of a microtiter plate-based screen for inhibitors of conversion of dTDP-glucose to dTDPrhamnose. Antimicrob Agents Chemother. 2001; 45(5), 1407-1416.

Madhusudan, SK, Misra AK. Facile exchange of glycosyl S,S-acetals to their O,O-acetals and preparation of glycofuranosides from acyclic glycosyl S,S-acetals under metal-free reaction conditions in the presence of 1,3-dibromo5,5-dimethylhydantoin. Carbohydr Res. 2005, 340, 497-502.

McAuliffe JC, Hindsgaul O. Use of acyclic glycosyl donors for furanoside synthesis. J Org Chem. 1997;62(5), 1234-1239.

Morgenlie S. Derivatives of alpha-DGalactofuranose. Acta Chem Scand. 1973; 27, 3609-3611.

Pacsu E, Green, J W. New synthesis of glycofuranosides. J Am Chem Soc, 1936; 58(9), 1823-1824.

Pearson RG. Recent advances in the concept of hard and soft acids and bases. J Chem Ed. 1987; 64(7), 561.

Peltier P, Euzen R, Daniellou R, NugierChauvin C, Ferrieres V. Recent knowledge and innovations related to hexofuranosides: structure, synthesis and applications. Carbohydr Res. 2008 343(12), 1897-1923.

Plavec J, Thibaudeau C, Chattopadhyaya J. How do the energetics of the stereoelectronic gauche and anomeric effects modulate the conformation of nucleos ( $\mathrm{t}$ ) ides?. Pure Appl Chem. 1996; 68(11), 2137-2144.

Rauter AP, Ramoa-Riberio F, Fernanders, AC, Figueiredo JA. A new method of acetonation with the zeolite HY as catalyst. Synthesis of $O$-Isopropylidene sugar derivatives. Tetrahedron. 1995; 51, 6529-6532. 
Repetto, E., Marino, C., \& Varela, O. Synthesis of the $(1 \rightarrow \quad 6)$-linked thiodisaccharide of galactofuranose: Inhibitory activity against a $\beta$-galactofuranosidase. Bioorg Med Chem. 2013; 21(11), 3327-3333.

Röse. L. Role of undecaprenyl phosphokinase in mycobacteria. Diss. HumboldtUniversitätzu Berlin, MathematischNaturwissenschaftliche Fakultät I. 2004.

Rose NL, Completo, GC; Lin, S-J; McNeil, MR; Palcic, MM; Lowary, TL. Expression, Purification and Characterization of a Galactofuranosyl-transferase Involved in Mycobacterium tuberculosis Arabinogalactan Biosynthesis. J. Am. Chem. Soc. 2006, 128, 6721-6729.

Shi Z, Sun L, LC. Solvent Polarity-Controlled Selective Synthesis of Methyl Pyranoside and Furanoside. J Agric Food Chem. 2014;62(14), 3287-3292.

Stallforth P, Lepenies B, Adibekian A, Seeberger, PH. Carbohydrates: a frontier in medicinal chemistry. J Med Chem. 2009; 52(18), 5561-5577.

Szarek WA, Zamojski A, Tiwari KN, Ison ER. A new, facile method for cleavage of acetals and dithioacetals in carbohydrate derivatives. Tetrahedron Lett. 1986; 27, 3827-3830.

Tefsen B, Ram AF, van Die I, Routier, FH. Galactofuranose in eukaryotes: aspects of biosynthesis and functional impact. Glycobiology. 2012; 22(4), 456-469.
Tsuji S, Uehori, J, Matsumoto M, Suzuki Y, Matsuhisa A, Toyoshima $\mathrm{K}$, et al. Human intelectin is a novel soluble lectin that recognizes galactofuranose in carbohydrate chains of bacterial cell wall. J Biol Chem. 2001; 276(26), 23456-23463.

Varki A. Biological roles of oligosaccharides: all of the theories are correct. Glycobiology. 1993; 3(2), 97-130.

Velty R, Benvegnu T, Gelin M, Privat E, Plusquellec D. A convenient synthesis of disaccharides containing furanoside units. Carbohydr. Res. 1997, 299, 7-14.

Wang $H$, Zhang G, Ning J. First synthesis of $\beta-d-G a l f-(1 \rightarrow 3)-d-G a l p$ - the repeating unit of the backbone structure of the $\mathrm{O}$-antigenic polysaccharide present in the lipopolysaccharide (LPS) of the genus Klebsiella. Carbohydr Res. 2003; 338, 10331037.

Wolfrom ML, Weisblat DI. Monothioacetals of Galactose. J Am Chem Soc.1940; 62(4), 878-880.

Wolfrom, ML, Weisblat DI, Hanze AR. The Reactivity of the Monothioacetals of Glucose and Galactose in Relation to Furanoside Synthesis. J Am Chem Soc. 1944; 66, 20652068.

Zemplén G, Mester, L, Messmer A. Darstellung der Thio-aldonsäurephenylhydrazide durch Einwirkung von Schwefelwasserstoff auf Zucker-Formazane. Chem Ber. 1953; 86, 697-699. 